\title{
"Employability-miles" and worker employability awareness
}

Citation for published version (APA):

Gerards, R., de Grip, A., \& Witlox, M. A. (2012). "Employability-miles" and worker employability awareness. METEOR, Maastricht University School of Business and Economics. METEOR Research Memorandum No. 042 https://doi.org/10.26481/umamet.2012042

Document status and date:

Published: 01/01/2012

DOI:

10.26481/umamet.2012042

Document Version:

Publisher's PDF, also known as Version of record

\section{Please check the document version of this publication:}

- A submitted manuscript is the version of the article upon submission and before peer-review. There can be important differences between the submitted version and the official published version of record.

People interested in the research are advised to contact the author for the final version of the publication, or visit the DOI to the publisher's website.

- The final author version and the galley proof are versions of the publication after peer review.

- The final published version features the final layout of the paper including the volume, issue and page numbers.

Link to publication

\footnotetext{
General rights rights.

- You may freely distribute the URL identifying the publication in the public portal. please follow below link for the End User Agreement:

www.umlib.nl/taverne-license

Take down policy

If you believe that this document breaches copyright please contact us at:

repository@maastrichtuniversity.nl

providing details and we will investigate your claim.
}

Copyright and moral rights for the publications made accessible in the public portal are retained by the authors and/or other copyright owners and it is a condition of accessing publications that users recognise and abide by the legal requirements associated with these

- Users may download and print one copy of any publication from the public portal for the purpose of private study or research.

- You may not further distribute the material or use it for any profit-making activity or commercial gain

If the publication is distributed under the terms of Article $25 \mathrm{fa}$ of the Dutch Copyright Act, indicated by the "Taverne" license above, 


\section{Maastricht University}

Ruud Gerards, Andries de Grip, Maaike Witlox

"Employability-miles" and worker employability awareness

RM/ 12/042

\section{METEOR}

Maastricht University School of Business and Economics

Maastricht Research School of Economics

of Technology and Organization

\section{P.O. Box 616}

NL - 6200 MD Maastricht

The Netherlands 


\title{
"Employability-miles" and worker employability awareness.
}

\author{
Ruud Gerards* , Andries de Grip ${ }^{\S}$ and Maaike Witlox $₫$
}

\begin{abstract}
This article studies the use and impact of a firm-sponsored training ("Employabilitymiles") voucher scheme that aims to stimulate employees to develop a more active attitude toward their own employability. Using data from two surveys of the firm's workforce, we find that voucher use is related to various personality traits and personal characteristics. In particular, a worker's ambition, goal setting, and education level are positively related to voucher use. In addition, women and those with longer tenure spend their vouchers more often. Conversely, workers with a more positive self-image as well as those who are negatively reciprocal spend their vouchers less often. The negative relation between voucher use and negative reciprocity suggests that workers who are more negatively reciprocal perceive the voucher as a threat. Further, we find that voucher use positively affects worker employability awareness and willingness to train. Remarkably, participation in non-voucher training shows little relation to personality traits. From a human resources perspective, this finding suggests that by employing a voucher scheme, the firm makes training participation more dependent on employee personality and individual characteristics instead of human resources practices.
\end{abstract}

JEL codes:

Keywords: Voucher, human capital, training, employability

${ }^{*}$ Department of Economics, ROA, NSI, and CofFEE-Europe, Maastricht University; e-mail R.Gerards@maastrichtuniversity.nl; Corresponding author, Department of Economics, Maastricht University, P.O. Box 616, NL-6200 MD Maastricht, The Netherlands; phone +31 43 3883821; fax +31 433884150.

${ }^{\S}$ Department of Economics, ROA, and NSI, Maastricht University, P.O. Box 616, NL-6200 MD Maastricht, The Netherlands, and the Institute for the Study of Labor (IZA), Bonn, Germany.

『School of Business and Economics, Maastricht University.

We thank Lex Borghans, Didier Fouarge, Joop Hartog, Hans Heijke, Joan Muysken, Arjan Non and Trudie Schils for their helpful comments. 


\section{INTRODUCTION}

Various studies show that worker employability is threatened by both the globalization of product and service markets and skills-biased technological change (e.g., Feenstra and Hanson (1996); Strauss-Kahn (2003); Geishecker (2006)). Conversely, training has been shown to increase worker employability (e.g., Groot and Maassen van den Brink (2000); Sanders and De Grip (2004)). In turn, increasing employability is shown to have positive effects on worker careers and is crucial for maintaining firms' competitive advantage (Heijde and Van Der Heijden (2006)). For these reasons firms may consider encouraging their workforce to participate in training. Voucher schemes are one instrument designed to stimulate worker participation in training and are used in numerous firms (Breugel et al. (2011)).

This article examines one firm's training voucher scheme. The scheme aims to stimulate firm employees to develop a more active attitude toward their own employability, that is, to increase their "employability awareness." This article analyzes which workers use the vouchers and whether voucher use increases worker employability awareness and their willingness to participate in further training.

Using data from two surveys of the firm's workforce, we find that voucher use is related to personality traits as well as to other personal characteristics. In particular, a worker's ambitions, goal setting, and education level are positively related to voucher use. In addition, women and those with longer tenure spend their vouchers more often. Conversely, workers with higher self-image and negative reciprocity spend their vouchers less often. The negative relation between voucher use and negative reciprocity is alarming from the firm's perspective, since it suggests that workers with greater negative reciprocity perceive the voucher as a threat to their job security rather than an encouragement to improve their employability. Further, we find that voucher use positively affects worker employability awareness and worker willingness to train. Remarkably, participation in non-voucher training is only minimally related to personality traits. From a human resources (HR) perspective, this suggests that by employing a voucher scheme, the firm makes training participation more dependent on employee personality and individual characteristics.

The voucher scheme we analyze is run by Philips Electronics Netherlands and is called Employability miles, or E-miles. On January 1, 2009, all employees received a voucher with a face value of 1,000 E-miles, regardless of their job or contract. These vouchers could be used for participation in a restricted number of training courses that attempt to contribute to worker employability awareness. The vouchers could not be used for any other training courses. In the remainder of this article the term voucher use is therefore synonymous with participation in employability awareness training. Workers could only redeem their voucher in the 2009 calendar year. The voucher expired on December 31, 2009.

We first examine which workers use their vouchers. Building on the existing literature, we focus on the role of personality traits (e.g., Leuven, Oosterbeek, Sloof, and van Klaveren (2005)) and personal characteristics (e.g., Booth (1991); Barron, Black, and Loewenstein (1993); Arulampalam, Booth, and Bryan (2004)). Our data include information not only 
on voucher use, but also on participation in other (regular) training courses not included in the voucher scheme (non-voucher training). Therefore, we also analyze which workers participate in non-voucher training and use this as a benchmark for our results with regard to the use of the training vouchers.

Next, we analyze whether workers who use their vouchers show increased employability awareness compared to workers who did not use their vouchers. Employability awareness is measured via five survey questions for which we compare the outcomes between the two survey moments. Finally, we analyze whether willingness to train is affected by voucher use.

Since the term employability can be interpreted in many ways (see De Grip, Van Loo, and Sanders (2004) for a history of the term), we clearly define our interpretation of employability as follows (De Grip et al. (2004), p. 216):

'Employability refers to the capacity and willingness of workers to remain attractive for the labor market (supply factors), by reacting to and anticipating changes in tasks and work environment (demand factors), facilitated by the human resource development instruments available to them (institutions).'

The remainder of this article is structured as follows. Section II discusses three relevant strands of the literature: the effects of voucher schemes, the relation between personality traits and training, and the incidence of training. Building on this literature, we formulate several hypotheses that guide our empirical analysis. Section III presents our data and the details of the particular voucher scheme we analyze. This includes information on the questions we use to measure worker employability awareness and willingness to train. Section IV presents the results of our empirical analyses and relates the results to our hypotheses. Section V sets forth our conclusions.

\section{LiterATURE}

\section{II.A. Voucher schemes}

Messer and Wolter (2009) conducted an experiment in which 2,437 randomly selected Swiss citizens received an adult education voucher. The recipients were free to select any adult education choice. The vouchers had three different face values $(200,750$, and 1,500 Swiss francs). Messer and Wolter (2009) find a redemption rate of 18.4\%. However, redemption rates differ significantly by face value category. A breakdown by voucher value reveals that the voucher with the highest value has double the impact on training participation as that of intermediate-value vouchers, whereas vouchers with a lower face value only create a deadweight loss. Further, these authors find a deadweight loss of roughly $60 \%$ for all redeemed vouchers. This means that many vouchers were used to participate in training that the participants would have taken anyway without the voucher. This deadweight loss is highest for the more highly educated, for whom it amounts to $91.4 \%$. Additionally, Messer and Wolter find that voucher redemption occurs mainly among more highly educated females. Based on the same data used by Messer and Wolter (2009), Schwerdt, Messer, Woessmann, 
and Wolter (2011) analyze the effect of voucher use on earnings and employment. However, these authors find no significant effects.

Van der Steeg, Elk, and Webbink (2010) examine a training voucher scheme for teachers in the Netherlands. Unique to this voucher scheme, teachers must apply for a voucher and vouchers are assigned on a first-come, first-served basis. Because obtaining a voucher is competitive and an active effort is required, these authors' results cannot be generalized to a voucher scheme in which individuals obtain a voucher without first applying for it. Nevertheless, some of their results are in line with those of Messer and Wolter (2009). Van der Steeg et al. (2010) also find that the introduction of a voucher scheme has a limited impact on training participation. Out of every 10 vouchers, only one is used for a training course that would not have been taken without the voucher. Eight out of every 10 vouchers are spent on training courses that voucher recipients would have taken anyway, which concurs with the finding of Messer and Wolter (2009), where vouchers schemes can lead to large deadweight losses.

The analysis of the voucher scheme described in this article differs slightly from those in the above-mentioned studies. In this article, the main focus is on two questions: (1) Which personality traits and personal characteristics of workers are related to voucher use and (2) do workers who redeem their vouchers actually perform differently with regard to the desired outcomes for the variables of the voucher scheme (i.e., worker employability awareness and worker willingness to train)? Since the training courses offered under the voucher scheme are designed to increase workers' employability awareness, we expect that voucher users improve their employability awareness compared to those who did not use their vouchers (hypothesis 1). Similarly, we expect a positive relation between voucher use and worker willingness to train (hypothesis 2).

\section{II.B. Personality traits and training participation}

There is a large body of theoretical and empirical literature on the incidence of training and whether workers or firms bear its costs. Standard human capital theory predicts that firms will not invest in general training because workers may leave the firm after receiving training (Becker (1962)). However, more recent literature provides various theoretical explanations for firm investment in general training (e.g., Katz and Ziderman (1990); Stevens (1994); Acemoglu and Pischke (1998, 1999a and 1999b); Lazear (2009); Booth and Katic (2011)). One departure from standard theory focuses on the role of personality traits in training participation. Building on the literature in this field, our analysis includes various personality traits, ranging from reciprocal feelings to career ambition. ${ }^{12}$

Leuven et al. (2005) are among the first investigators to introduce reciprocity in the empirical training literature. They base their definition of reciprocity on that of Fehr and Gächter (2000), who define it as an individual's response to a friendly action as "frequently

\footnotetext{
${ }^{1}$ Our selection of personality traits builds on the results of a meta-analysis by Colquitt, LePine, and Noe (2000).

${ }^{2}$ The survey questions we use to measure workers' personality traits are listed in the Appendix.
} 
much nicer and much more cooperative than predicted by the self-interested model" (p. 159). The same holds for unfriendly actions, to which reciprocal individuals respond in a manner that is much more "nasty and even brutal" (p. 159) than standard theory would predict. Positive reciprocity refers to cooperative responses while negative reciprocity refers to retaliatory responses (Fehr and Gächter (2000)). The model that Leuven et al. (2005) use represents an adjustment to an earlier reciprocity theory of Dufwenberg and Kirchsteiger (2000). That model shows that a firm's investment in general training may be affected by a worker's sensitivity with respect to reciprocity. A firm's investment in general training can be perceived as a "kind" action. The worker, in return, can reward this kind action by not leaving the firm after having taken the training. The firm can anticipate this positive reciprocity by investing more in general training. The main finding of Leuven et al. (2005) is that workers who are driven by positive reciprocal motives are more likely to participate in training. Building on these findings, we expect that positive reciprocity is positively related to the use of vouchers. In addition, we expect that negative reciprocity is negatively related to voucher use. Since the voucher scheme was introduced in the midst of the global financial crisis and Philips Netherlands has undergone a number of large-scale reorganizations, workers may have perceived the employability voucher as a threat. Workers who are more driven by negative reciprocal behavior may respond to this perceived threat by refusing to use their vouchers.

Whether workers believe that the (positive or negative) results from their actions are due to their own efforts depends on their locus of control. Individuals with an internal locus of control share the opinion that their own successes and failures are attributable to their own actions and decisions. Noe (1986) argues that people with an internal locus of control feel that they can control their environment. This is the reason that such individuals take opportunities that may increase their probability of receiving rewards such as promotions, pay increases, or recognition (Noe (1986), p. 739). Conversely, individuals who have an external locus of control believe that work outcomes can be attributed to luck, fate, specific circumstances, or the actions of people around them. Noe (1986) finds that workers with an internal locus of control participate in training more often. Colquitt et al. (2000) confirm this finding. Therefore, our expectation is that workers with a more internal locus of control are more likely to use their vouchers.

Anxiety is a measure of whether individuals fear situations with which they are not familiar. Fear of exams is a typical factor for which individuals with anxiety score high (Fouarge, Schils, and De Grip (2010)). Anxiety is found to be negatively related to worker motivation to learn (Colquitt et al. (2000); Webster and Martocchio (1993)), training participation, and the level of regret individuals show in the choices they make (Borghans, Golsteyn, and De Grip (2006)). Based on these results, we expect that anxiety is negatively related to voucher use.

Self-confidence is the extent to which individuals believe in themselves. Bénabou and Tirole (2002) conclude that "an individual's confidence in his abilities can help him to under- 
take more ambitious goals" (p. 872). Borghans et al. (2006) find that more highly educated individuals show a greater level of self-confidence. This effect may be self-reinforcing since another of these authors' findings is that self-confident individuals are more willing to participate in training and consequently participate more. Hence, we expect that self-confidence is positively related to voucher use.

Self-image is the extent to which individuals are able to reflect on who they are. Borghans et al. (2006) argue that individuals who have a positive self-image are better able to determine whether training is useful to them. However, this could affect workers' willingness to train either positively (if they think a particular course of training is useful to them) or negatively (if they think they do not need training).

We measure workers' imaginations by asking how they imagine their life will be in 15 years. Individuals with higher levels of imagination may also have a better picture of how training can contribute to this envisioned future. We therefore expect that imagination is positively related to voucher use.

Facteau, Dobbins, Russell, Ladd, and Kudisch (1995) find a relation between planning behavior and training motivation. Individuals with a high level of goal setting indicate that they set achievement goals. To set goals, individuals must first assess their current situation and compare it to their future desired situation. They must be aware of their strengths and weaknesses before they can set relevant goals. Individuals may be more eager to participate in training because they know it can improve their weaknesses, leading to a greater willingness to participate (Colquitt et al. (2000)). Hence, we expect that goal setting is positively related to voucher use.

Career ambition can also be a driver of training participation (Colquitt et al. (2000)). We measure workers' career ambition by the extent to which they picture themselves switching to a different firm within five years. An ambitious career attitude means that the individual wishes to develop and probably has a clear view of the role that training can have in this respect (e.g., Mathieu, Martineau, and Tannenbaum (1993); Facteau et al. (1995)). Therefore, we expect that career ambition is positively related to voucher use.

The above overview of the literature expresses the direction in which we expect each of several personality traits to affect voucher use. We thus set forth the hypothesis that each personality trait affects voucher use in the expected direction (hypothesis 3 ).

\section{II.C. Personal characteristics and training participation}

The literature on the incidence and duration of training generally finds that younger and more highly educated workers are more likely to participate in training (Bassanini, Booth, Brunello, De Paola, and Leuven (2007)). Therefore, we expect that worker age is negatively related and education is positively related to voucher use.

With respect to gender, the results from the literature are mixed. Studies in the 1980s and 1990s often find that women report a higher training incidence than men, but these courses were short in duration, leading to the conclusion that women receive less training (e.g., 
Altonji and Spletzer (1991)). However, more recently Bassanini et al. (2007) find that women are more likely to participate in training and that this includes training of longer duration. However, the gender difference that Bassanini et al. (2007) find is small and disappears when these authors focus their analysis on employer-sponsored training only (rather than all training courses), suggesting that the higher training participation of female workers is related to training courses that they pay for themselves. O'Halloran (2008), however, shows results that are in line with the literature of the 1980s and 1990s; that is, women have a higher incidence of training but the duration of this training is shorter. Finally, Dieckhoff and Steiber (2010) find that women receive less training than men. Messer and Wolter (2009) find that women are more likely to use their vouchers than men. Moreover, the courses offered through the E-miles voucher scheme that we analyze are very short (maximum of one day) and much shorter than the average for non-voucher training. Therefore, we expect that women are more likely to use their vouchers than men.

With respect to the relation between worker tenure and training participation, the findings from the literature are also mixed. Loewenstein and Spletzer (1997) and Croce and Tancioni (2007) find that training increases with tenure, because just after hiring, initial uncertainty about the job match reduces training incentives. However, Frazis, Gittleman, and Joyce (2000) find no significant effect of tenure on the probability of training, whereas Bassanini et al. (2007) find a U-shaped relation between tenure and training. The latter argue that, initially, new employees need to be trained to adapt to the requirements of the new job, after which further training is delayed, in line with the findings of Loewenstein and Spletzer (1997). These studies evaluate the relation between training and tenure as a decision concerning to whom the firm wants to offer training opportunities. However, in our study, the firm supplied a voucher to all employees, guaranteeing a training supply. As a result, the relation between voucher use and tenure can be explained only from the perspective of the workers themselves. We expect that tenure is positively related to voucher use because workers with short tenure have been hired more recently and have therefore recently been active in the job search process. This provides them "confirmation" of their employability, whereas those with longer tenure may be more uncertain about their employability and may therefore be more eager to use their E-miles vouchers.

The overview of the literature above expresses the direction in which we expect each personal characteristic to affect voucher use. We hypothesize that each personal characteristic affects the use of vouchers in the expected direction (hypothesis 4 )

\section{II.D. Schematic overview}

Figure 1 summarizes the structure of our analysis and hypotheses. All dependent variables are shown in italics. All dependent variables are either rank order outcomes or 0/1 dummies. We use ordered logit or logit estimators, which enables us to report odds ratios, providing an enhanced interpretation of the results. ${ }^{3}$ In addition, we estimate a treatment

\footnotetext{
${ }^{3}$ Using ordered probit or probit leads to very similar results that do not change any interpretation or conclusion.
} 
effects model to correct for possible endogeneity of voucher use.

Figure 1: Structure of the empirical analysis and hypotheses.

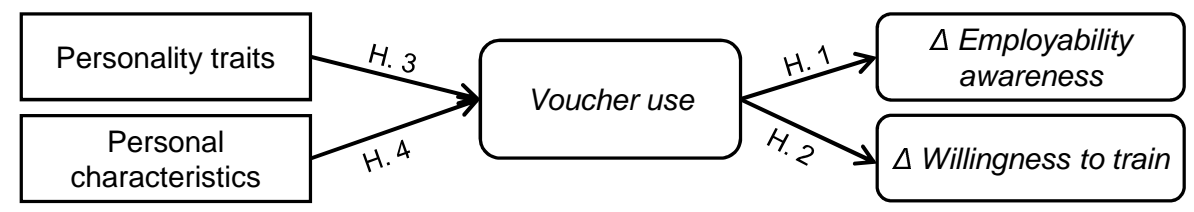

\section{DATA}

Our data come from two surveys that we conducted in cooperation with Philips Netherlands. The first survey took place in December 2008, before the introduction of the voucher scheme. At that time, employees were not yet informed about the introduction of the voucher scheme. Therefore, this first survey establishes a baseline. The second survey took place in February 2010, that is, just after the expiration date of the 2009 voucher. Both surveys addressed various aspects of the training, personality traits, the workplace, and voucher use. Most survey questions were yes/no or a five-point Likert scale, allowing workers to indicate to what extent they (dis-)agree with a given statement. Both surveys were conducted among a randomly drawn sample of 2,500 regular employees. The response rate in both surveys was $38 \%$. Personal characteristics were collected in the first survey. To be able to use these personal characteristics in our analysis, only those individuals who responded to both surveys were retained in our sample. This leads to a sample of 648 individuals who responded to both surveys. ${ }^{4}$ With respect to several observable characteristics, these respondents are representative of the workforce of Philips Netherlands. ${ }^{5}$

\section{III.A. Descriptives}

Table I provides an overview of the training courses offered through the voucher scheme and the amount of E-miles needed per course. Before the start of the voucher scheme, all employees received information on the voucher via e-mail. This e-mail also included information about the various training courses offered. Enrollment for training took place via online registration. The E-check course requires all the E-miles a worker has received; the self-insight training is also relatively expensive. Employability advice, career pit-stop,

\footnotetext{
${ }^{4}$ There could be a bias in our results, which are based on our sample of 648 individuals who responded to both surveys, because the sample only includes those who "stayed" with Philips. However, by analyzing email server bounces we identified only 32 persons as possible "leavers" because their e-mail address returned a server bounce at the second survey. T-tests on several key personal characteristics and survey questions show that these 32 individuals have similar characteristics and give similar answers to key questions as those respondents who stayed at Philips.

${ }^{5}$ The average age of respondents is 44 and the average age of Philips' total workforce is 43 . In both cases, more than $60 \%$ of the population is male. Further, respondents have 12 years of education on average and Philips' total workforce has 13 years of education on average. Finally, respondents have an average of 17 years of tenure, whereas this figure is 13 years for the total Philips population. However, the standard deviation of our sample's tenure is 11 . So the sample mean may not be statistically different from the population mean. Since we do not have data on the population standard deviation, we cannot test this.
} 
Table I: Voucher training courses

\begin{tabular}{l|lr}
\hline \hline Training & Content & E-miles required \\
\hline E(mployability)- check & $\begin{array}{l}2 \text { hour computer test, 1 hour individual } \\
\text { evaluation with career counselor }\end{array}$ & 1,000 \\
Self-insight & $\begin{array}{l}30 \text { minutes computer test, 1 hour individual } \\
\text { evaluation with career counselor }\end{array}$ & 700 \\
Employability advice & $\begin{array}{l}\text { One hour individual consultation with } \\
\text { career counselor }\end{array}$ & 350 \\
Career pit-stop & $\begin{array}{l}\text { Workshop on career development, 4 hours } \\
\text { Route planner }\end{array}$ & 300 \\
\hline \hline
\end{tabular}

and route planner require fewer E-miles. Workers are allowed to spend their voucher on more than one training course.

From the sample of 648 employees, 123 (19\%) used their vouchers. This is a rather low percentage but in line with results from the studies discussed in Section II. For respondents who did not use their vouchers, the most important single reason given was "a lack of time" $(22 \%)$. Other reasons included "no interesting products in E-miles offer" (16\%) and "never heard of E-miles" (11\%). ${ }^{6}$ Figure 2 depicts the share of vouchers spent on the various training courses in 2009. More than half of the vouchers were spent on the most expensive training course, E-check, requiring the entire amount of E-miles. Around $30 \%$ of workers spent their voucher on the self-insight course (the second most expensive training course) and almost one-quarter of voucher users spent their vouchers on the employability advice. The career pit-stop was used by only $6 \%$. One-third of the workers who used their vouchers purchased only one of the low-priced training courses, thus not spending all their E-miles. ${ }^{7}$

Panels A and B of Figure 3 show voucher use by age and tenure, respectively. Younger workers and workers with shorter tenure have a relatively high voucher redemption rate. Further, voucher use appears to be far more popular among female workers. Whereas only $15.5 \%$ of male workers used their vouchers, almost $26 \%$ of female workers spent their E-miles.

\footnotetext{
${ }^{6}$ A total of $38 \%$ answered "other reason," $7 \%$ answered "not enough support from manager," and $3 \%$ answered "registration for courses was too complicated." The remaining $3 \%$ were split among several other answers.

${ }^{7}$ Since the route planner was not taken by any of the respondents, it is omitted from Figure 2.
} 
Figure 2: Voucher training taken

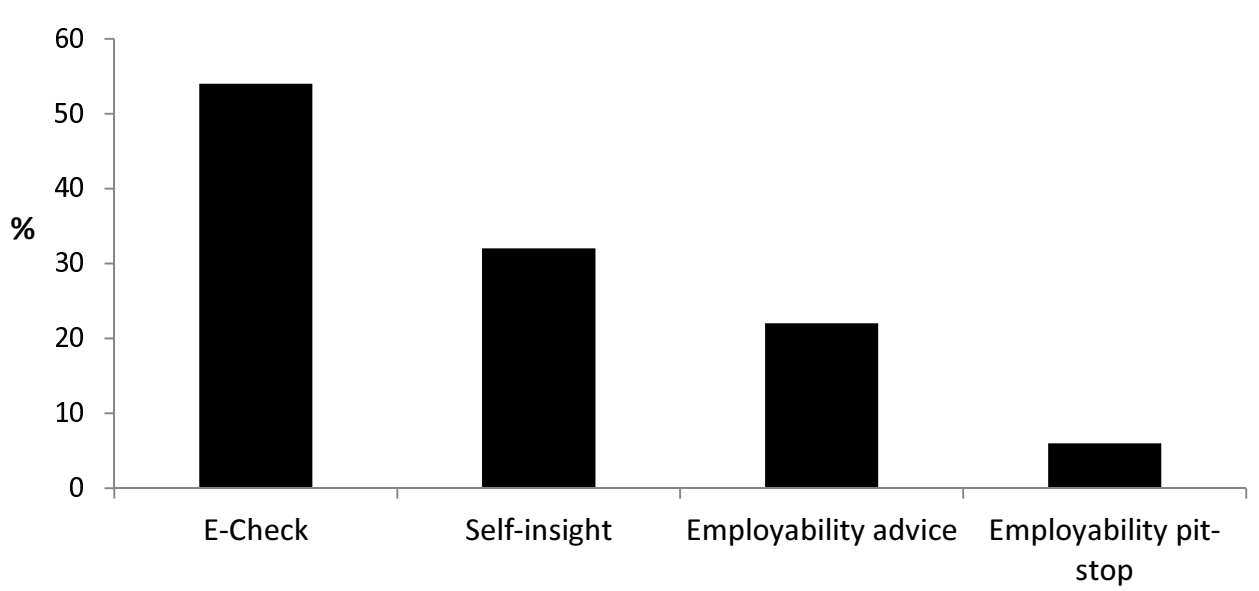

Figure 3: Voucher use by age (Panel A) and tenure (Panel B)
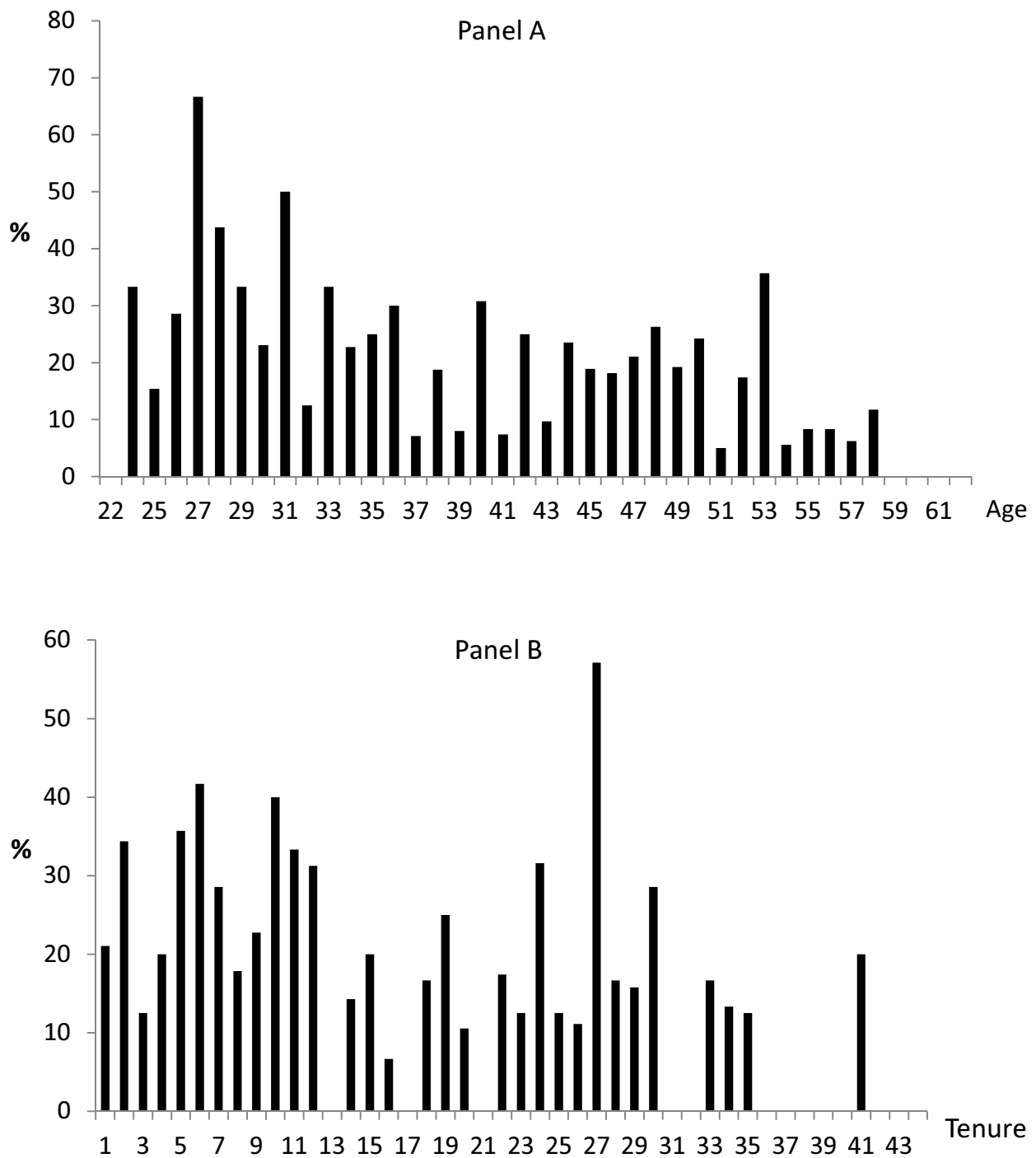
Table II shows the means and standard deviations of the variables included in the empirical analyses. The remainder of this section discusses the descriptive statistics for the variables used in our analysis.

Table II: Descriptive statistics of the sample

\begin{tabular}{|c|c|c|c|c|c|c|c|c|}
\hline & \multicolumn{3}{|c|}{ Survey 1} & \multicolumn{3}{|c|}{ Survey 2} & \multirow[b]{2}{*}{ Min } & \multirow[b]{2}{*}{ Max } \\
\hline & Obs. & Mean & s.d. & Obs. & Mean & s.d. & & \\
\hline Training participation & & & & & & & & \\
\hline 1 if used voucher & 0 & - & - & 646 & 0.19 & 0.39 & 0 & 1 \\
\hline 1 if took non-voucher trn. & 636 & 0.61 & 0.49 & 633 & 0.43 & 0.50 & 0 & 1 \\
\hline \multicolumn{9}{|l|}{ Personality traits ${ }^{8}$} \\
\hline Locus of control & 585 & 2.88 & 0.99 & - & - & - & 1 & 5 \\
\hline Self-confidence & 583 & 2.63 & 1.14 & - & - & - & 1 & 5 \\
\hline Anxiety & 577 & 2.24 & 1.13 & - & - & - & 1 & 5 \\
\hline Self-image & 576 & 3.97 & 0.83 & - & - & - & 1 & 5 \\
\hline Imagination & 586 & 3.36 & 1.20 & - & - & - & 1 & 5 \\
\hline Positive reciprocity & 594 & 4.06 & 0.78 & - & - & - & 1 & 5 \\
\hline Negative reciprocity & 596 & 2.43 & 0.87 & - & - & - & 1 & 5 \\
\hline Goal setting & 603 & 3.62 & 1.02 & - & - & - & 1 & 5 \\
\hline Career ambition & 599 & 2.28 & 0.93 & - & - & - & 0.75 & 4 \\
\hline \multicolumn{9}{|l|}{ Personal characteristics } \\
\hline Age & 639 & 43.62 & 9.30 & - & - & - & 22 & 62 \\
\hline 1 if female & 635 & 0.36 & 0.48 & - & - & - & 0 & 1 \\
\hline Years of education & 636 & 12.20 & 2.66 & - & - & - & 6 & 16 \\
\hline Tenure & 639 & 17.04 & 11.18 & - & - & - & 1 & 44 \\
\hline \multicolumn{9}{|l|}{ HR practices (1 if yes $)^{a}$} \\
\hline Assessment interviews & 627 & $95 \%$ & & 616 & $95 \%$ & & & \\
\hline Personal development plan & 611 & $47 \%$ & & 609 & $47 \%$ & & & \\
\hline Feedback on a regular basis & 614 & $56 \%$ & & 607 & $60 \%$ & & & \\
\hline Task/job rotation & 610 & $44 \%$ & & 605 & $40 \%$ & & & \\
\hline Mid-year review & 610 & $53 \%$ & & 609 & $55 \%$ & & & \\
\hline \multicolumn{9}{|l|}{ Sector $^{b}$} \\
\hline Consumer Lifestyle & 648 & $16 \%$ & & - & - & - & & \\
\hline Healthcare & 648 & $22 \%$ & & - & - & - & & \\
\hline Lighting & 648 & $34 \%$ & & - & - & - & & \\
\hline Other & 648 & $27 \%$ & & - & - & - & & \\
\hline
\end{tabular}

${ }^{a}$ Percentage of workers that report this instrument is used/offered by their manager/outlet.

${ }^{b}$ Percentage of workers that work in this sector.

\section{III.B. Dependent variables}

Voucher use and participation in non-voucher training was measured by straightforward yes/no questions. Employability awareness was assessed by asking the workers to reply to a number of statements on a five-point Likert scale. These statements are as follows:

\footnotetext{
${ }^{8}$ Personality traits are assumed to remain constant over time. Even though this is not necessarily the case, many economists and psychologists use this assumption (see, e.g., Borghans, Duckworth, Heckman, and Ter Weel (2008)).
} 
1. I myself am responsible for my future development.

2. I have a clear view of how I want to develop myself in the years to come.

3. I know what I need to do to achieve my goals at work.

4. Would you like to have a new job within Philips in the next five years?

5. Would you like to have a new job outside Philips in the next five years?

The definition of employability we use (see Section I) includes two dimensions: worker willingness and worker capacity (De Grip et al. (2004), p. 217): "The first - willingness - measures peoples' desire to engage in activities that keep them attractive on the labor market. The second - capacity - is concerned with the power to develop one's position on the labor market."

These two dimensions can be further broken down into a number of indicators of employability (Bolweg and Maenhout (1995); De Grip et al. (2004)). All five statements we use to measure employability awareness relate to one of the indicators of employability. Statements 1 and 2 refer to the "capacity to participate in training," statement 3 to the "capacity to be mobile," and statements 4 and 5 to the "willingness to be mobile." The more positively workers respond to each of these statements, the more active their attitude is and the higher we assess their employability awareness. We measure workers' willingness to train (also one of the indicators of employability) via a question that attempts to indicate whether workers want to spend leisure time on training participation:

- If it were possible to take a one-year training course for which you have to study eight hours per week (in your leisure time) and in return you might get a 5\% salary increase, would you take the training?

\section{III.C. Independent variables}

The personality traits listed in Table II are measured on a five-point Likert scale. A higher score means that the respondent exhibits the corresponding personality trait to a greater extent. All personality traits are measured using three questions. Our analysis uses standard factors of these variables when Cronbach's alpha was sufficiently high (over 0.7, based on Peterson (1994)). The Appendix lists all questions per construct and, where applicable, Cronbach's alpha. For constructs for which Cronbach's alpha was too low, only one of the questions was used to represent that particular personality trait. In these cases, we used the question with the most prominent results. Table II shows that respondents have, on average, a relatively high score (a mean around three out of five or higher) for being able to create a self-image, being able to imagine the future, positive reciprocity, and goal setting. Conversely, respondents have, on average, relatively low levels of anxiety, negative reciprocity, and career ambition. The relatively low career ambition may be related to the fact that Philips is commonly viewed as one of the most popular employers in the 
Netherlands, combined with the fact that our measure of career ambition measures only external ambition (the ambition to continue one's career outside Philips). Since our sample already works with Philips, they may already be very content with this achievement, which may relate to the lower (external) career ambition.

Several personal characteristics are included in the analyses. Respondents were asked to report their age, tenure, gender, and education level. ${ }^{9}$ We measure respondents' level of education by converting Dutch educational attainment levels to the related nominal years of education. The average age of all respondents is 44 and the sample contains more male than female respondents. Respondents have, on average, 12 years of education and an average tenure of 17 years. This set of averages on personal characteristics may provide a further clue about the relatively low career ambition overall. At middle age with substantial tenure and no higher education, workers may simply not have much ambition remaining. Employing many workers with these characteristics makes the relevance of the E-miles program and its attention to employability relatively higher than if the average age and tenure were much lower and the level of education higher.

We control for several factors that may affect the dependent variable. These control variables are $\mathrm{HR}$ practices and the sector in which respondents work. With regard to HR practices, respondents were asked to indicate whether a particular practice had been used by their manager or department (yes/no). Table II includes the firm's HR practices.

\section{Results}

\section{IV.A. Which workers use their vouchers?}

Table III shows a series of binomial logit estimations on the use of E-miles vouchers. Column 1 shows the results of an estimation without the control variables, whereas column 2 includes sector dummies and column 3 includes both the sector dummies and the various HR practices. The final column reports the odds ratios for variables that have significant coefficients. The odds ratio shows the factor with which the probability of voucher use increases, as the value of the respective independent variable increases by one unit.

The table shows that the personality traits locus of control, goal setting, and career ambition are positively related to the use of vouchers. These results confirm our expectations formulated in Section II.B with regard to these variables. The odds ratio for career ambition shows that if career ambition increases by one unit, the probability of voucher use increases by 1.44. All other odds ratios can be interpreted similarly. It is not surprising that workers with higher career ambitions are more likely to use the opportunity that E-miles provide to assess their current and future employability. The negative relation between negative reciprocity and voucher use confirms our expectation. The weakly significant negative coefficient for self-image suggests that workers who have a better self-image less often think they need to improve their employability awareness.

\footnotetext{
${ }^{9} \mathrm{Age}^{2}$ and tenure ${ }^{2}$ are included in our regression analyses.
} 
Table III: Voucher redemption

\begin{tabular}{|c|c|c|c|c|}
\hline & \multicolumn{4}{|c|}{1 if used voucher } \\
\hline & 1 & 2 & 3 & Odds ratio $^{a}$ \\
\hline Locus of control & $\begin{array}{l}0.254 * * \\
(0.130)\end{array}$ & $\begin{array}{c}0.243 * \\
(0.132)\end{array}$ & $\begin{array}{c}0.254 * \\
(0.133)\end{array}$ & 1.28 \\
\hline Self-confidence & $\begin{array}{c}0.151 \\
(0.110)\end{array}$ & $\begin{array}{c}0.137 \\
(0.110)\end{array}$ & $\begin{array}{c}0.133 \\
(0.111)\end{array}$ & \\
\hline Anxiety & $\begin{array}{c}-0.021 \\
(0.112)\end{array}$ & $\begin{array}{c}-0.017 \\
(0.113)\end{array}$ & $\begin{array}{c}-0.010 \\
(0.114)\end{array}$ & \\
\hline Self-image & $\begin{array}{r}-0.257 * \\
(0.153)\end{array}$ & $\begin{array}{r}-0.267 * \\
(0.153)\end{array}$ & $\begin{array}{r}-0.271 * \\
(0.156)\end{array}$ & 0.76 \\
\hline Imagination & $\begin{array}{c}0.054 \\
(0.101)\end{array}$ & $\begin{array}{c}0.041 \\
(0.102)\end{array}$ & $\begin{array}{c}0.057 \\
(0.103)\end{array}$ & \\
\hline Pos reciprocity & $\begin{array}{c}0.037 \\
(0.136)\end{array}$ & $\begin{array}{c}0.043 \\
(0.136)\end{array}$ & $\begin{array}{c}0.039 \\
(0.137)\end{array}$ & \\
\hline Neg reciprocity & $\begin{array}{r}-0.252 * \\
(0.133)\end{array}$ & $\begin{array}{c}-0.276 * * \\
(0.135)\end{array}$ & $\begin{array}{c}-0.281 * * \\
(0.139)\end{array}$ & 0.76 \\
\hline Goal setting & $\begin{array}{l}0.295 * * \\
(0.129)\end{array}$ & $\begin{array}{l}0.300 * * \\
(0.129)\end{array}$ & $\begin{array}{l}0.294 * * \\
(0.132)\end{array}$ & 1.34 \\
\hline Career ambition & $\begin{array}{l}0.414 * * * \\
(0.119)\end{array}$ & $\begin{array}{l}0.378 * * * \\
(0.121)\end{array}$ & $\begin{array}{l}0.366 * * * \\
(0.125)\end{array}$ & 1.44 \\
\hline Age & $\begin{array}{c}-0.005 \\
(0.137)\end{array}$ & $\begin{array}{c}0.011 \\
(0.139)\end{array}$ & $\begin{array}{c}-0.014 \\
(0.139)\end{array}$ & \\
\hline $\mathrm{Age}^{2}$ & $\begin{array}{c}-0.000 \\
(0.002)\end{array}$ & $\begin{array}{c}-0.000 \\
(0.002)\end{array}$ & $\begin{array}{c}-0.000 \\
(0.002)\end{array}$ & \\
\hline 1 if female & $\begin{array}{c}0.411 * \\
(0.247)\end{array}$ & $\begin{array}{c}0.383 \\
(0.253)\end{array}$ & $\begin{array}{c}0.376 \\
(0.255)\end{array}$ & 1.51 \\
\hline Years of education & $\begin{array}{l}0.151 * * * \\
(0.053)\end{array}$ & $\begin{array}{l}0.159 * * * \\
(0.055)\end{array}$ & $\begin{array}{l}0.143 * * \\
(0.057)\end{array}$ & 1.15 \\
\hline Tenure & $\begin{array}{c}0.099 * \\
(0.053)\end{array}$ & $\begin{array}{c}0.091 * \\
(0.054)\end{array}$ & $\begin{array}{c}0.093 * \\
(0.054)\end{array}$ & 1.10 \\
\hline Tenure $^{2}$ & $\begin{array}{r}-0.002 * \\
(0.001)\end{array}$ & $\begin{array}{c}-0.002 \\
(0.001)\end{array}$ & $\begin{array}{c}-0.002 \\
(0.001)\end{array}$ & 1.00 \\
\hline Constant & $\begin{array}{r}-4.910 \\
(3.010) \\
\end{array}$ & $\begin{array}{r}-5.667 * \\
(3.058) \\
\end{array}$ & $\begin{array}{r}-5.118 \\
(3.146) \\
\end{array}$ & \\
\hline $\begin{array}{c}\text { Controls included }^{b}: \\
\text { Sector dummies } \\
\text { HR practices }\end{array}$ & $\begin{array}{l}\text { No } \\
\text { No }\end{array}$ & $\begin{array}{l}\text { Yes } \\
\text { No }\end{array}$ & $\begin{array}{l}\text { Yes } \\
\text { Yes }\end{array}$ & \\
\hline Pseudo $\mathrm{R}^{2}$ & 0.11 & 0.12 & 0.13 & \\
\hline Observations & 510 & 510 & 510 & \\
\hline $\begin{array}{l}\text { Standard errors in } \\
a \text { The odds ratios a } \\
\text { except for the odds } \\
\text { based on the estima } \\
{ }^{b} \text { See Table II for ar }\end{array}$ & $\begin{array}{l}\text { entheses. } \\
\text { always base } \\
\text { tios of the } \\
\text { s of column } \\
\text { verview of }\end{array}$ & $\begin{array}{l}\text { k* } \mathrm{p}<0.01,^{*} \\
\mathrm{~d} \text { on the est } \\
\text { ender dumn } \\
\text { one. } \\
\text { he control v }\end{array}$ & $\begin{array}{l}\mathrm{p}<0.05, * \\
\text { mates in the } \\
\mathrm{y} \text { and tenure } \\
\text { riables }\end{array}$ & $\begin{array}{l}<0.1 \\
\text { hird column, } \\
\text {, which are }\end{array}$ \\
\hline
\end{tabular}


Most personal characteristics included in the analyses do not significantly contribute to voucher use. Only education level shows a highly significant relation to voucher use, confirming our expectation. Column 1 shows a weakly positive coefficient for female workers on voucher use. For tenure, we also find a weakly significant positive relation to voucher use. However, voucher use is not significantly related to worker age.

Of the included sets of HR control variables, only the mid-year review is positively significant. Workers who had a mid-year review used their voucher more often in the second half of the year than those who did not have a mid-year review. This suggests that the mid-year review was possibly used to remind those who had not used their voucher yet to do so. ${ }^{10}$

Table IV shows a series of estimations on worker participation in non-voucher training. To compare these outcomes with those from voucher use in Table III, we use information from the second survey only. Of all the personality traits, only goal setting is significant, whereas negative reciprocity is only weakly significant when all control variables are included. From the set of personal characteristics, one highly significant result emerges: Women are less likely to participate in non-voucher training than men. None of the control variables have a significant impact on the probability of participation in non-voucher training.

Comparing the results from Tables III and IV, we observe that both personality traits and personal characteristics play a far more important role in voucher use than in nonvoucher training. Locus of control, self-image, negative reciprocity, goal setting, and career ambition all relate to voucher use across the three estimations, whereas only goal setting is consistently significant with regard to participation in non-voucher training. Further, the estimation results show that women are more likely to use their vouchers (although this result is weakly significant) but less likely to participate in non-voucher training. Other personal characteristics such as education and tenure also relate to voucher use, whereas they do not relate to participation in non-voucher training. From an HR perspective, these differences suggest that by employing a voucher scheme, the firm makes training participation more dependent on employee personality and individual characteristics. Section V elaborates on this interpretation.

Although not reported in a table, we also ran the estimations from Table IV using observations from both surveys while clustering on the individual. Here we find that the HR practices of a personal development plan and a mid-year review are significantly positively related to participation in non-voucher training. This suggests that participation in nonvoucher training is more likely a decision made by the line manager or jointly made by the manager and worker and formalized in a personal development plan or mid-year review.

\footnotetext{
${ }^{10}$ There were also some differences between sectors. Workers in the lighting sector were more prone to use their vouchers than workers in the consumer lifestyle sector, reflecting differences in culture between these sectors.
} 
Table IV: Participation in non-voucher training

\begin{tabular}{|c|c|c|c|}
\hline & \multicolumn{3}{|c|}{1 if participated in non-voucher training } \\
\hline & 1 & 2 & 3 \\
\hline$\overline{\text { Locus of control }}$ & $\begin{array}{c}-0.070 \\
(0.099)\end{array}$ & $\begin{array}{c}-0.070 \\
(0.100)\end{array}$ & $\begin{array}{c}-0.076 \\
(0.101)\end{array}$ \\
\hline Self-confidence & $\begin{array}{c}-0.085 \\
(0.088)\end{array}$ & $\begin{array}{r}-0.086 \\
(0.088)\end{array}$ & $\begin{array}{c}-0.082 \\
(0.089)\end{array}$ \\
\hline Anxiety & $\begin{array}{c}0.095 \\
(0.088)\end{array}$ & $\begin{array}{c}0.094 \\
(0.088)\end{array}$ & $\begin{array}{c}0.081 \\
(0.090)\end{array}$ \\
\hline Self-image & $\begin{array}{c}-0.141 \\
(0.125)\end{array}$ & $\begin{array}{r}-0.140 \\
(0.126)\end{array}$ & $\begin{array}{c}-0.139 \\
(0.128)\end{array}$ \\
\hline Imagination & $\begin{array}{c}-0.051 \\
(0.080)\end{array}$ & $\begin{array}{r}-0.064 \\
(0.081)\end{array}$ & $\begin{array}{r}-0.068 \\
(0.081)\end{array}$ \\
\hline Pos reciprocity & $\begin{array}{c}0.085 \\
(0.101)\end{array}$ & $\begin{array}{c}0.087 \\
(0.102)\end{array}$ & $\begin{array}{c}0.092 \\
(0.103)\end{array}$ \\
\hline Neg reciprocity & $\begin{array}{c}0.157 \\
(0.098)\end{array}$ & $\begin{array}{c}0.152 \\
(0.099)\end{array}$ & $\begin{array}{r}0.171 * \\
(0.100)\end{array}$ \\
\hline Goal setting & $\begin{array}{l}0.247 * * \\
(0.098)\end{array}$ & $\begin{array}{l}0.247 * * \\
(0.099)\end{array}$ & $\begin{array}{l}0.242 * * \\
(0.100)\end{array}$ \\
\hline Career ambition & $\begin{array}{r}0.169 * \\
(0.094)\end{array}$ & $\begin{array}{c}0.141 \\
(0.096)\end{array}$ & $\begin{array}{c}0.149 \\
(0.099)\end{array}$ \\
\hline Age & $\begin{array}{c}0.028 \\
(0.105)\end{array}$ & $\begin{array}{c}0.046 \\
(0.106)\end{array}$ & $\begin{array}{c}0.038 \\
(0.107)\end{array}$ \\
\hline $\mathrm{Age}^{2}$ & $\begin{array}{c}-0.001 \\
(0.001)\end{array}$ & $\begin{array}{c}-0.001 \\
(0.001)\end{array}$ & $\begin{array}{c}-0.001 \\
(0.001)\end{array}$ \\
\hline 1 if female & $\begin{array}{c}-0.667 * * * \\
(0.204)\end{array}$ & $\begin{array}{l}-0.719 * * * \\
(0.210)\end{array}$ & $\begin{array}{c}-0.704 * * * \\
(0.211)\end{array}$ \\
\hline Years of education & $\begin{array}{c}-0.024 \\
(0.041)\end{array}$ & $\begin{array}{r}-0.024 \\
(0.043)\end{array}$ & $\begin{array}{r}-0.032 \\
(0.044)\end{array}$ \\
\hline Tenure & $\begin{array}{r}-0.020 \\
(0.038)\end{array}$ & $\begin{array}{r}-0.027 \\
(0.038)\end{array}$ & $\begin{array}{r}-0.025 \\
(0.039)\end{array}$ \\
\hline Tenure $^{2}$ & $\begin{array}{c}0.000 \\
(0.001)\end{array}$ & $\begin{array}{c}0.000 \\
(0.001)\end{array}$ & $\begin{array}{c}0.000 \\
(0.001)\end{array}$ \\
\hline Constant & $\begin{array}{c}0.388 \\
(2.366)\end{array}$ & $\begin{array}{r}-0.108 \\
(2.396)\end{array}$ & $\begin{array}{l}0.153 \\
(2.455)\end{array}$ \\
\hline $\begin{array}{r}\text { Controls included }^{a} \text { : } \\
\text { Sector dummies }\end{array}$ & No & Yes & Yes \\
\hline HR practices & No & No & Yes \\
\hline Pseudo $\mathrm{R}^{2}$ & 0.06 & 0.06 & 0.07 \\
\hline Observations & 509 & 509 & 509 \\
\hline
\end{tabular}




\section{IV.B. Does voucher use increase employability awareness?}

Table V shows the estimation results of ordered logit regressions on the relation between voucher use and changes $\left(t_{2}-t_{1}\right)$ in five indicators of worker employability awareness and willingness to train. In all regressions, the dependent variable measures the difference in employability awareness or willingness to train between December 2008, before the introduction of the voucher system, and February 2010, immediately after the expiration date of the vouchers. For each dependent $t_{2}-t_{1}$ change variable, we ran an ordered logit regression, including various sets of controls. ${ }^{11}$ By analyzing the difference between $t_{2}$ and $t_{1}$, we correct for selection effects that may otherwise occur with regard to the initial level of the dependent variable.

Table $\mathrm{V}$ shows that workers who used their vouchers experienced a positive change in their employability awareness compared to workers who did not redeem their vouchers. This holds for four components of employability awareness: responsibility for one's future development, knowing what to do to achieve goals at work, having a clear view of how to develop in the next few years, and aspiring to a new job with Philips in the next five years. The variable measuring workers' ambition to work outside Philips within the next five years is not significant. With four out of five variables being significant, these results largely confirm hypothesis 1 . However, Table $\mathrm{V}$ also shows that those who used their vouchers did not show a significantly different change in their willingness to train than those who did not use their vouchers. Thus, hypothesis 2 cannot be confirmed on the basis of this estimation.

\footnotetext{
${ }^{11}$ Regressions with varying sets of controls provide robust results.
} 


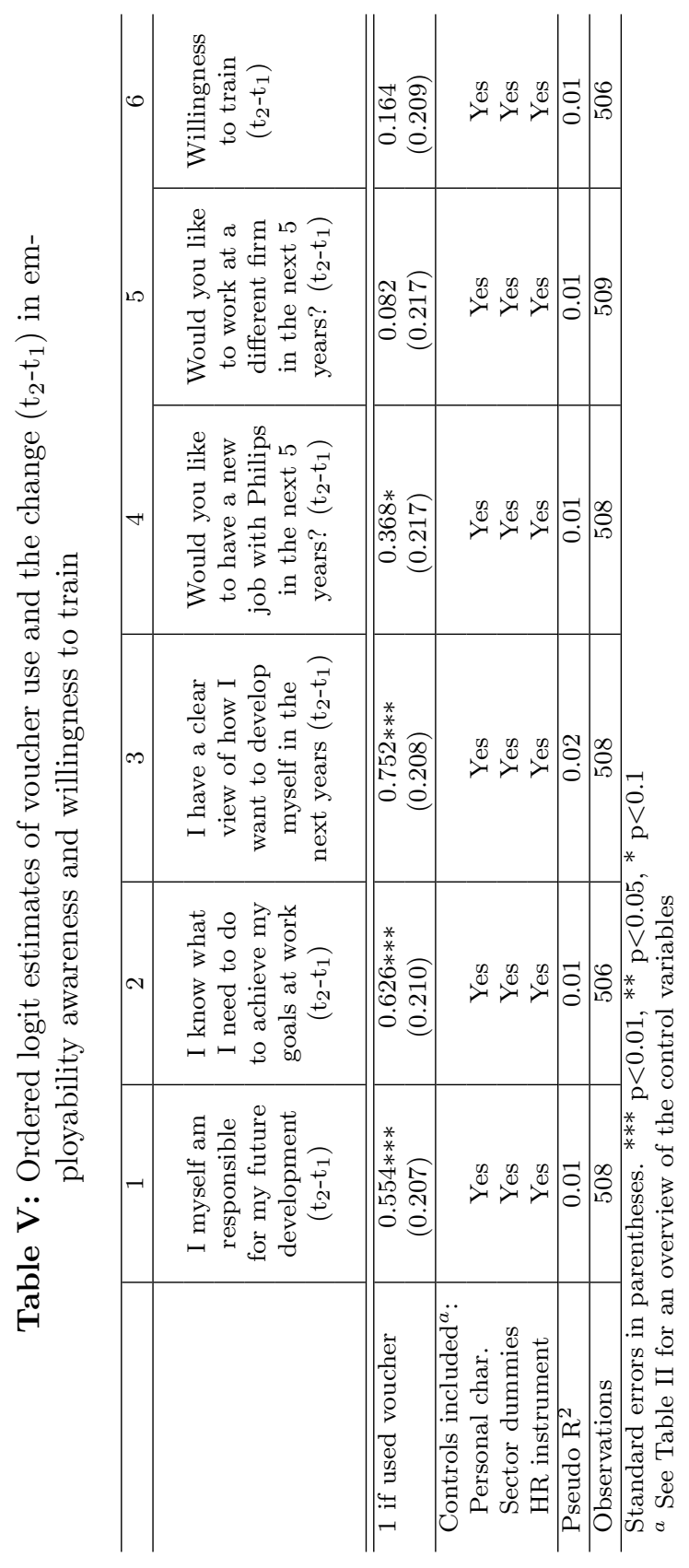


The estimations reported in Table $\mathrm{V}$ correct for selection effects that may occur with respect to the initial level of the dependent variable. To correct for the possibility of timevarying unobserved variables, we estimate a treatment effects model that simultaneously estimates voucher use and its effect on the relevant $t_{2}-t_{1}$ change variable. In the first stage voucher use is estimated with the same variables as in Table III: personality traits, personal characteristics, the sector, and HR practices. The outcomes are the same as those in Table III. ${ }^{12}$ The second stage then estimates the effect of voucher use on the relevant dependent variable. Table VI reports the results of these treatment effect estimations. The likelihood ratio test of independent equations rejects the null hypothesis of independence for all estimations, confirming the endogeneity problem and the need to use this treatment effects model. Therefore, this is our preferred estimator.

The estimation results show that voucher use significantly affects all measures of employability awareness as well as the willingness to train. The significant positive coefficients for voucher use in columns 1 to 3 of Table VI confirm the results in Table V. The coefficient for aspiring to a new job with Philips in the next five years turns out to be negative and significant in the treatment effects model, whereas it is positive and weakly significant in the ordered logit estimates. The coefficient for aspiring to a new job in a different firm in the next five years is now significant and positive, whereas it is insignificant in Table V. The negative significant coefficient for "within Philips mobility ambition" and the positive coefficient for "outside Philips mobility ambition" shows that voucher use increases firm external employability awareness at the cost of internal mobility ambitions. These outcomes further confirm hypothesis 1. Finally, column 6 of Table VI shows that voucher use is positively related to worker willingness to train, confirming hypothesis 2 .

\footnotetext{
${ }^{12}$ Only the size of the coefficient differs, since the treatment effects model uses a probit instead of a logit estimator for the first stage.
} 


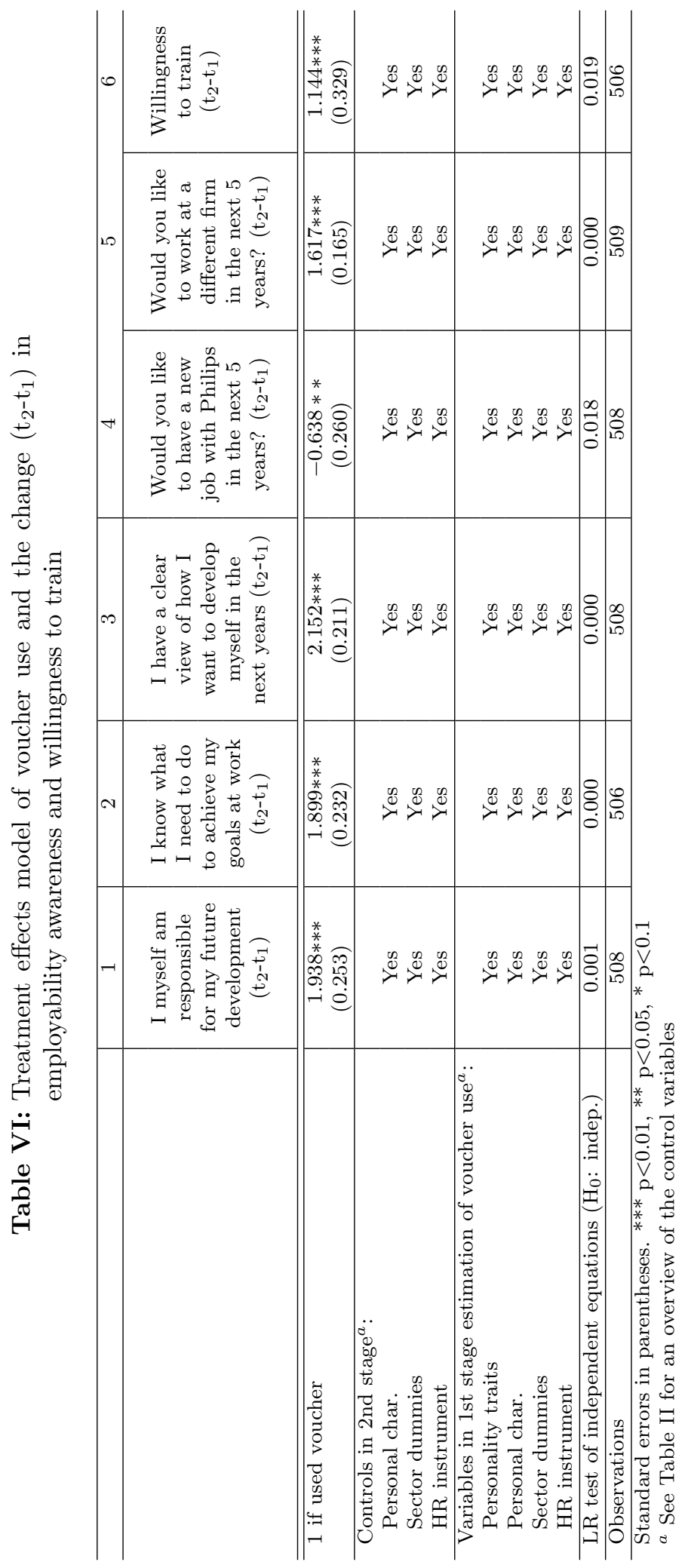




\section{Discussion AND CONCLUSIONS}

This article analyzes a firm's training voucher scheme to determine (1) which workers use their vouchers and (2) whether the vouchers increase workers' employability awareness and willingness to participate in further training. Overall, voucher redemption is low, at $19 \%$, which is similar to the findings of other studies on voucher schemes.

We find that voucher use is related to various personality traits and personal characteristics. Voucher use is higher for workers with a more internal locus of control, as well as higher levels of goal setting, career ambition, education, and tenure. In particular, goal setting and career ambition, which embody the ability to reflect on the future, have the highest odds ratios. Moreover, we find (with weak significance) that women redeem their vouchers more often than men. Workers with higher levels of self-image and negative reciprocity use their vouchers less often. The negative relation between self-image and voucher use shows that workers with a lower self-image are more likely to use their vouchers, which is positive, since the voucher training courses are designed to increase worker employability awareness, and, as such, should aid in improving worker self-image. However, the negative relation between voucher use and negative reciprocity is alarming from the firm's perspective, since this finding suggests that workers who behave with greater negative reciprocity perceive the voucher as a threat. Since the timing of the voucher scheme coincided with the global financial crisis, workers with greater negative reciprocity may have perceived the employability vouchers as a signal that the firm wanted to reduce its workforce.

We benchmark the findings with regard to voucher use against an analysis of worker participation in non-voucher training. Contrary to voucher use, we find that, apart from goal setting, participation in non-voucher training is not significantly related to personality traits or personal characteristics. We conclude that the more significant role of personality traits and personal characteristics in voucher use is a result of the design of the voucher system. All workers were given a voucher and the firm thereby guaranteed the opportunity to train for all workers. The workers decided for themselves whether they would use their vouchers. Since this was their own individual decision, their personalities and personal backgrounds affected their decisions. From an HR perspective, this suggests that by employing a voucher scheme, the firm makes training participation more dependent on employee personality and individual characteristics. This enables the firm to reveal the ambitions of its workforce. Conversely, participation in non-voucher training is determined by management decision making or a joint decision of the worker and a manager. This decision depends particularly on available time, budget, and return on investment. The latter factor is underscored by the positive relation between participation in non-voucher training and the use of HR practices such as personal development plans and mid-year reviews. These HR practices are typically used to formalize agreements between workers and management about workers' work-related development and the role training has in this development.

Furthermore, we find that the voucher scheme positively affects the employability awareness of workers who used their vouchers. We find these effects by analyzing the development 
of various indicators of worker employability awareness between the two surveys. All indicators show that the employability awareness of workers who used their vouchers significantly improves compared to those who did not use their vouchers. Moreover, the analysis shows that workers who used their vouchers show a significantly positive change in their willingness to train compared to workers who did not use their vouchers.

Overall, the voucher scheme appears to achieve the goal it was designed for: It significantly increases employability awareness among those who spent their vouchers. However, our results also show that the workers who are more likely to use their vouchers are those who already had higher levels of ambition and education, an internal locus of control, and a lower level of negative reciprocity. One can argue that workers with these traits and characteristics are those who have relatively less to gain from employability training because they are already better equipped to withstand future threats to their employability than workers who have less education and ambition, an external locus of control, and a higher level of negative reciprocity. As we argue above, workers who are more driven by negative reciprocal behavior may perceive the voucher as a threat to their employability, whereas the voucher was intended to be a stepping stone to improve workers' employability. This suggests that voucher redemption can be further optimized if the voucher system and the communications around it are designed to minimize the scope within which voucher recipients can view the system with suspicion. 


\section{REFERENCES}

Acemoglu, D., Pischke, J., 1998. Why do firms train? Theory and evidence. Quarterly Journal of Economics 113 (1), 79-118.

Acemoglu, D., Pischke, J., 1999a. Beyond Becker: training in imperfect labour markets. The Economic Journal 109 (453), 112-142.

Acemoglu, D., Pischke, J., 1999b. The structure of wages and investment in general training. Journal of Political Economy 107 (3), 539-572.

Altonji, J., Spletzer, J., 1991. Worker characteristics, job characteristics, and the receipt of on-the-job training. Industrial and Labor Relations Review 45 (1), 58-79.

Arulampalam, W., Booth, A., Bryan, M., 2004. Training in Europe. Journal of the European Economic Association 2 (2-3), 346-360.

Barron, J., Black, D., Loewenstein, M., 1993. Gender differences in training, capital, and wages. The Journal of Human Resources 28 (2), 343-364.

Bassanini, A., Booth, A., Brunello, G., De Paola, M., Leuven, E., 2007. Workplace training in Europe (in G.Brunello, P.Garibaldi and E.Wasmer (Ed.). Education and Training in Europe). Oxford University Press, Oxford.

Becker, G., 1962. Investment in human capital: a theoretical analysis. The Journal of Political Economy 70 (5), 9-49.

Bénabou, R., Tirole, J., 2002. Self-confidence and personal motivation. Quarterly Journal of Economics 117 (3), 871-915.

Bolweg, J., Maenhout, J., 1995. Full-employability: Economisch noodzakelijk, sociologisch naief? In L.Faase, M. Ott and C.J. Voss (eds.): Nieuwe Breukvlakken in het Arbeidsbestel: Balans van 10 jaar veranderingen in Nederland en België. 10, 92-99.

Booth, A., 1991. Job-related formal training: who receives it and what is it worth? Oxford Bulletin of Economics and Statistics 53 (3), 281-294.

Booth, A., Katic, P., 2011. Men at work in a land down-under: Testing some predictions of human capital theory. British Journal of Industrial Relations 49 (1), 1-24.

Borghans, L., Duckworth, A., Heckman, J., Ter Weel, B., 2008. The economics and psychology of cognitive and non-cognitive traits. Journal of Human Resources 43 (4), 972-1059.

Borghans, L., Golsteyn, B., de Grip, A., 2006. Meer werken is meer leren: determinanten van kennisontwikkeling. CINOP.

Breugel, G. v., Grip, A. d., Dohmen, D., 2011. Ontwikkelingscheque, uitwerking advies denktank leren en werken. Research Centre for Education and the Labour Market (ROA).

Colquitt, J., LePine, J., Noe, R., 2000. Toward an integrative theory of training motivation: A meta-analytic path analysis of 20 years of research. Journal of Applied Psychology $85(5), 678$.

Croce, G., Tancioni, M., 2007. Disentangling factors behind training participation in Italy. Univ. of Rome, Dept. of Economics Working Paper No. 101.

De Grip, A., Van Loo, J., Sanders, J., 2004. The industry employability index: Taking 
account of supply and demand characteristics. International Labour Review 143 (3), 211233.

Dieckhoff, M., Steiber, N., 2010. A re-assessment of common theoretical approaches to explain gender differences in continuing training participation. British Journal of Industrial Relations.

Dufwenberg, M., Kirchsteiger, G., 2000. Reciprocity and wage undercutting. European Economic Review 44 (4-6), 1069-1078.

Facteau, J., Dobbins, G., Russell, J., Ladd, R., Kudisch, J., 1995. The influence of general perceptions of the training environment on pretraining motivation and perceived training transfer. Journal of Management 21 (1), 1.

Feenstra, R., Hanson, G., 1996. Globalization, outsourcing, and wage inequality. The American Economic Review 86 (2), 240-245.

Fehr, E., Gächter, S., 2000. Fairness and retaliation: The economics of reciprocity. The Journal of Economic Perspectives 14 (3), 159-181.

Fouarge, D., Schils, T., De Grip, A., 2010. Why do low-educated workers invest less in further training? IZA Discussion Papers.

Frazis, H., Gittleman, M., Joyce, M., 2000. Correlates of training: an analysis using both employer and employee characteristics. Industrial and Labor Relations Review, 443-462.

Geishecker, I., 2006. Does outsourcing to Central and Eastern Europe really threaten manual workers' jobs in Germany? The World Economy 29 (5), 559-583.

Groot, W., Maassen van den Brink, H., 2000. Education, training and employability. Applied Economics 32, 573-581.

Heijde, C., Van Der Heijden, B., 2006. A competence-based and multidimensional operationalization and measurement of employability. Human resource management 45 (3), $449-476$.

Katz, E., Ziderman, A., 1990. Investment in general training: the role of information and labour mobility. The Economic Journal 100 (403), 1147-1158.

Lazear, E., 2009. Firm-specific human capital: A skill-weights approach. Journal of Political Economy 117 (5), 914-940.

Leuven, E., Oosterbeek, H., Sloof, R., Van Klaveren, C., 2005. Worker reciprocity and employer investment in training. Economica 72 (285), 137-149.

Loewenstein, M., Spletzer, J., 1997. Delayed formal on-the-job training. Industrial and Labor Relations Review, 82-99.

Mathieu, J., Martineau, J., Tannenbaum, S., 1993. Individual and situational influences on the development of self-efficacy: implications for training effectiveness. Personnel Psychology 46 (1), 125-147.

Messer, D., Wolter, S., 2009. Money matters: Evidence from a large-scale randomized field experiment with vouchers for adult training. CESifo, Center for Economic Studies and Ifo Institute for economic research. 
Noe, R., 1986. Trainees' attributes and attitudes: Neglected influences on training effectiveness. The Academy of Management Review 11 (4), 736-749.

O’Halloran, P. L., December 2008. Gender differences in formal on-the-job training: Incidence, duration, and intensity. Labour 22 (4), 629-659.

Peterson, R., 1994. A meta-analysis of Cronbach's coefficient alpha. Journal of consumer research, 381-391.

Sanders, J., De Grip, A., 2004. Training, task flexibility and the employability of low-skilled workers. International Journal of Manpower 25 (1), 73-89.

Schwerdt, G., Messer, D., Woessmann, L., Wolter, S., 2011. Effects of adult education vouchers on the labor market: Evidence from a randomized field experiment. IZA Discussion Papers 5431.

Stevens, M., 1994. A theoretical model of on-the-job training with imperfect competition. Oxford Economic Papers 46 (4), 537-562.

Strauss-Kahn, V., 2003. The role of globalization in the within-industry shift away from unskilled workers in France. NBER Working Papers.

Van der Steeg, M., Elk, R. v., Webbink, D., 2010. Het effect van de lerarenbeurs op scholingsdeelname docenten. CPB document no. 205.

Webster, J., Martocchio, J., 1993. Turning work into play: Implications for microcomputer software training. Journal of Management 19 (1), 127-146. 


\section{ApPEndiX: SuRVEy Questions}

Table VII: Survey questions corresponding with variables*

\begin{tabular}{|c|c|c|}
\hline Variable & $s_{1}$ & $\begin{array}{l}\text { Cron. } \\
\text { Alpha }\end{array}$ \\
\hline \multicolumn{3}{|l|}{ Personality traits: } \\
\hline Locus of control & - Setbacks can usually be blamed on other people. & \\
\hline Self-confidence & - I have the tendency to think someone else is better than I am. & \\
\hline Anxiety & - I am scared of going to places where I have not been before. & \\
\hline Self-image & - Generally, I have a clear picture of who I am and what I am capable of. & \\
\hline Imagination & - Sometimes I imagine what my life will look like in 15 years. & \\
\hline Negative reciprocity & $\begin{array}{l}\text { - If someone treats me unfair, I will do anything I can to take revenge. } \\
\text { - If I feel offended by someone, I will do the same to him. } \\
\text { - If someone puts me in a unfavorable position, I will do the same to him. }\end{array}$ & 0.81 \\
\hline Positive reciprocity & $\begin{array}{l}\text { - When someone pleases me, I am willing to give something in return. } \\
\text { - I always try to help someone who has helped out in the past. } \\
\text { - I am willing to provide effort in order to help someone who has helped me } \\
\text { out in the past. }\end{array}$ & 0.78 \\
\hline Career ambition & $\begin{array}{l}\text { - Would you like to work for a different company in five years from now? } \\
\text { - Do you think you will work for a different firm in five years from now? }\end{array}$ & 0.75 \\
\hline Goal setting & - I set goals in what I want to achieve. & \\
\hline \multicolumn{3}{|l|}{ Employability awareness } \\
\hline $\begin{array}{l}\text { Responsibility for } \\
\text { future development }\end{array}$ & - I myself am responsible for my future development. & \\
\hline Clarity of approach & - I know what I need to do to achieve my goals at work. & \\
\hline $\begin{array}{l}\text { Image of future } \\
\text { self development }\end{array}$ & - I have a clear view of how I want to develop myself in the next years. & \\
\hline New job within five years & - Would you like to have a new job within Philips in the next five years? & \\
\hline Willingness to train & $\begin{array}{l}\text { - If it were possible to take a one-year training course for which you have to } \\
\text { study eight hours per week (in your leisure time) and in return you might } \\
\text { get a } 5 \% \text { salary increase, would you take the training? }\end{array}$ & \\
\hline \multicolumn{3}{|l|}{ Control variables } \\
\hline $\begin{array}{l}\text { HR practices } \\
\text {-Assessment interviews } \\
\text {-Personal dev. plan } \\
\text {-Regular feedback } \\
\text {-Task/job rotation } \\
\text {-Mid-year review }\end{array}$ & $\begin{array}{l}\text { Does the Philips outlet you work in use the following HR practices? (yes/no) } \\
\text { - Assessment interviews } \\
\text { - Assistance in making a personal development plan } \\
\text { - I get regular feedback from my direct superior } \\
\text { - The option of task/job rotation exists } \\
\text { - Development-interviews (mid-year reviews) are being held }\end{array}$ & \\
\hline $\begin{array}{l}\text { All questions in this table (e } \\
\text { (straightforward) questions } \\
\text { level as well as the sector in } \\
\text { *For some personality traits } \\
\text { turned out relatively low anc } \\
\text { for that personality trait. }\end{array}$ & $\begin{array}{l}\text { pt HR practices) are answered on a five-point Likert scale. The remaining } \\
\text { ed include personal characteristics: age, gender, tenure and education } \\
\text { ich employees work: consumer lifestyle, healthcare, lighting or other. } \\
\text { report only one question in this table. In these cases the Cronbach's alpha } \\
\text { e decided for our analyses, to use only the question reported in the table }\end{array}$ & \\
\hline
\end{tabular}

